Diabetologia 5, 279-283 (1969)

\title{
ORIGINALS
}

\section{Action of Some Hypoglycaemic Sulphonylureas on the Oxygen Consumption of Isolated Pancreatic Islets of Mice}

\author{
Harald Stork, Felix H. Schmidt, Sighild Westman and Clafes Hellerström* \\ Boehringer Mannheim GmbH., Germany and the Histological Department, University of Uppsala, \\ Uppsala, Sweden
}

Received: October 16, 1968

Summary. Cartesian divers were used to evaluate the effects in vitro of some hypoglycaemic sulphonylureas on the oxygen consumption of isolated pancreatic islets. The islet specimens were obtained from obese-hyperglycaemic mice, and consisted of over $90 \%$ B-cells. When incubated with Krebs-Ringer phosphate modium, the islet cells displayed an increased rate of respiration upon addition to the incubation medium of either tolbutamide (D $860 ; 0.1 \mathrm{mg} / \mathrm{ml}$ ) or glibenclamide (HB $419 ; 0.1 \mu \mathrm{g} /$ $\mathrm{ml})$. The respiratory rate increased with the concentration of $\mathrm{HB} 419$ in the range $0.001-0.1 \mu \mathrm{g} / \mathrm{ml}$, but did. not exceed $120 \%$ of the respiration in pure phosphate medium. Whereas the physiological excretion product of D 860 did not affect the respiratory rate, the corresponding derivative of $\mathrm{HB} 419$ was still effective in stimulating the oxygen uptake of the islets. When islets were incubated with glucose at a high concentration $(3 \mathrm{mg} / \mathrm{ml})$, the oxygen uptake was inhibited by addition of D 860, or its metabolite, or HB 419. The last drug slightly increased the respiration of islets incubated with glucose at a concentration of $1 \mathrm{mg} / \mathrm{ml}$, and a marked stimulation was noted at a still lower glucose concentration, $0.5 \mathrm{mg} / \mathrm{ml}$. Attempts to evaluate the effect of mannoheptulose on the respira. tory response of the islets to hypoglycaemic sulphonylureas produced inconclusive results. It is suggested that sulphonylureas effect an increased rate of endogenous substrate oxidation in the B-cells of the pancreatic islets.

Action de certains sulfonylurées hypoglycémiants sur la consommation d'oxygène d'ilots pancréatiques isolés de souris

Résumé. L'action des sulfonylurées hypoglycémiants sur la consommation d'oxygène des îlots pancréatiques isolés a été déterminée in vitro à l'aide d'un microrespiro. mètre cartésien. Les îlots provenaient du pancréas de souris obèses hyperglycémiques et contenaient plus de $90 \%$ de cellules B. L'addition de tolbutamide (D 860; $0.1 \mathrm{mg} / \mathrm{ml}$ ) ou de glibenclamide (HB $419 ; 0.1 \mu \mathrm{g} / \mathrm{ml}$ ) au milieu d'incubation Krebs-Ringer-phosphate provoquait une augmentation de la consommation d'oxygène. La respiration augmentait avec la concentration de HB 419 entre 0.001 et $0.1 \mu \mathrm{g} / \mathrm{ml}$, mais ne dépassait pas $120 \%$ de la respiration dans le milieu phosphaté pur. Tandis que le métabolite d'excrétion physiologique du D 860 n'influencait pas la respiration, le dérivé correspondant du HB 419 stimulait encore la captation d'oxygène des îlots. Quand les îlots étaient incubés avec une forte concentration de glucose $(3 \mathrm{mg} / \mathrm{ml})$ la captation d'oxygène était inhibée par l'addition de $\mathrm{D} 860$, de son métabolite ou de HB 419. Cette dernière drogue augmentait légèrement la respiration des îlots incubés avec du glucose à la concentration de $1 \mathrm{mg} / \mathrm{ml}$, tandis que l'on notait une stimulation très marquée pour une concentration de glucose encore plus faible $(0.5 \mathrm{mg} / \mathrm{ml})$. Les tentatives pour évaluer l'effet du mannoheptulose sur la réponse respiratoire des îlots aux sulfonylurées hypgloycémiants n'ont pas donné des résultats concluants. Il semble que les sulfonylurées produisent une augmentation de l'oxydation des substrats endogènes dans les cellules $B$ des îlots pancréatiques.

Wirkung einiger blutzuckersenkender Sulfonylharnstoff-Verbindungen auf den Sauerstoffverbrauch isolierter Pankreas-Inseln bei Mäusen

Zusammenfassung. Der Einfluß blutzuckersenkender Sulfonylharnstoffe auf den $\mathrm{O}_{2}$-Verbrauch isolierter Pankreas-Inseln wurde in vitro mit dem cartesianischen Taucher bestimmt. Die Inseln entstammten den Pankreas von Mäusen mit dem obese-hyperglycemic-Syndrom und bestanden zu über $90 \%$ aus B-Zellen. Zusätze von Tolbutamid (D 860, $0.1 \mathrm{mg} / \mathrm{ml}$ ) oder Glibenclamid (HB 419,0.1 $\mu \mathrm{g} / \mathrm{ml}$ ) zu den in Krebs-Ringer-PhosphatPufferlösung inkubierten Inseln führten zu Steigerungen des Sauerstoffverbrauchs. Für HB 419 wurde im Bereich von 0.001 bis $0.1 \mu \mathrm{g} / \mathrm{ml}$ ein konzentrationsabhängiger Effekt von maximal $120 \%$ der Kontrollwerte nachgewie. sen. Das Hauptausscheidungsprodukt von D 860 hatte auf die Respirationsrate keine Wirkung. Der Metabolit von HB 419 steigerte dagegen signifikant den Sauerstoff. verbrauch. Wenn Inseln in Gegenwart hoher Glucosekonzentrationen $(3 \mathrm{mg} / \mathrm{ml}$ ) vorinkubiert wurden, dann wurde der Sauerstoffverbrauch durch Zusatz von D 860, seinem Metaboliten und auch von HB 419 gehemmt. Bei geringerer Glucosekonzentration von 0.5 und $1.0 \mathrm{mg} / \mathrm{ml}$ verursachte HB419 jedoch eine Steigerung des Sauerstoffverbrauchs. Der Stimulationseffekt von HB419 konnte einerseits durch nachfolgenden Zusatz von Mannoheptulose nicht unterdrückt werden, andererseits aber bei Vorinkubation der Inseln zusammen mit Mannoheptulose nicht mehr ausgelöst werden. Aus den Resultaten wird geschlossen, daß Sulfonylharnstoffe zu einer gesteigerten endogenen Substratoxydation in den B-Zellen der Langerhans'schen Inseln führen.

Key-words: Sulphonylureas, tolbutamide, glibenclamide, cartesian divers, pancreatic islets, metabolism of pancreatic B-cells, respiration of isolated islets, sulphonylurea effects on islets.
* This work was supported by the Swedish Medical Research Council (B 68-12X-109-04) and the U.S.Public Health Service (Grant AM-05759-06). The skilful technical assistance of Miss GuntmLa Leikselitus and Miss INGBRITT BROLEN is greatfully acknowledged.

\section{Introduction}

Already in his classical papers Loubatières [16, 17] suggested that the hypoglycaemic effect of certain sulphonamides is mediated principally through stimu- 
lation of insulin release from the B-cells of the pancreatic islets. Numerous subsequent studies with both sulphonamides and the closely related sulphonylureas have confirmed and extended this view, although it cannot be excluded that extra-pancreatic effects also contribute to the antidiabetic properties of these drugs $[7,8,23]$. The detailed mechanism by which they stimulate the B-cells to secrete insulin is, however, poorly understood. At least in part this may be attributed to difficulties inherent in metabolic studies of mammalian B-cells, which are collected in numerous minute islets dispersed throughout the exocrine pancreatic parenchyma. Recent techniques for isolation of surviving pancreatic islets and for metabolic microanalyses of these small preparations seem to offer new possibilities of evaluating the action of drugs on the B-cells. The experiments reported here were carried out to determine, in terms of oxygen consumption, the metabolic effects of sulphonylureas on the mammalian B-cells. For this purpose the respiration of isolated pancreatic islets of mice was measured in vitro in the presence of either tolbutamide or a new, highly potent, sulphonylurea compound designated as glibenclamide.

\section{Material and Methods}

Chemicals. D-mannoheptulose was generously given by Professor E. Simos of the Weizmann Institute of Science, Rehovoth, Israel. D.glucose was obtained from Baker Chemical Co., Phillipsburg, New Jersey, U.S.A. Tolbutamide (D 860), glibenclamide (HB $419)^{1}$ and their metabolic excretion products ${ }^{2}$ were supplied as sodium salts by Boehringer Mannheim GmbH, Germany. HB 419 is a recently synthesized benzamido-alkyl-benzolsulphonylurea derivative, which has a significant blood sugar lowering effect in several species including man, when given orally in doses of only $15-100 \mu \mathrm{g} / \mathrm{kg}$ body weight [1]. The therapeutic plasma concentration is of the order of $0.01-0.1 \mu \mathrm{g} / \mathrm{ml}$, as calculated from the relation between dose and space of distribution $[2,20]$; and that of tolbutamide is about $0.1 \mathrm{mg} / \mathrm{ml}[6]$.

The urinary excretion product of tolbutamide (D 860-COOH) in man, has a carboxyl group substituted for a methyl group in the molecule and lacks blood sugar lowering properties [24]. The main excretion product of $\mathrm{HB} 419$, which is a 4-hydroxy-cyclohexyl derivative (HB 419-OH) of the original substance, has a capacity for lowering the blood sugar that is consistently weaker than that of the original substance [13].

In the present experiments, the different sulphonylureas were solubilized by being dissolved first in equimolar amounts of $1 \mathrm{~N}$ sodium hydroxide and then diluted to the desired concentration with KrebsRinger phosphate medium [22]. The $\mathrm{pH}$-values of the solution were adjusted to 7.4 at $+37^{\circ} \mathrm{C}$ immediately before each experiment.

1,2 Jointly developed by Boehringer Mannheim GmbH and Farbwerke Hoechst AG. Frankfurt/M.-Hoechst.
Preparation of isolated islets. Altogether 33 female mice, 5 months old, with the obese-hyperglycaemic syndrome were used. The mouse strain originated from the Roscoe B. Jackson Memorial Laboratory, Bar Harbor, Maine, U.S.A., and has been bred at the Histological Department, University of Uppsala, since 1959. The animals had free access to water and a uniform diet (caloric composition; Mcal $/ \mathrm{kg}$ : $\mathrm{N}$-free extractable substances 1.98 , raw fat 0.20 , raw protein 0.70 , fibres $0.15)$ until $18 \mathrm{~h}$ before decapitation, when they were deprived of food. After exsanguination, the pancreas was quickly removed and suspended in Krebs-Ringer phosphate buffer [22] maintained at $+2^{\circ} \mathrm{C}$. The subsequent procedure for isolation of fresh pancreatic islets by microdissection has been described in detail previously [10].

Determination of the oxygen consumption. Isolated islets were incubated at $+37^{\circ} \mathrm{C}$ in the Cartesian diver micro-respirometer originally developed by HoLTER and LINDERSTRÖM-LANG [14]. After being filled, each diver had a gas space of about $5 \mu l$, which made the system sensitive to a change in the gas volume of about $5 \times 10^{-4} \mu l$. The amount of incubated tissue required for an individual experiment could therefore be limited to $1-2$ islets with a total dry weight of $1-10 \mu \mathrm{g}$. The technique for the filling of the divers. as well as the volumes and compositions of the various, neck seals, have been reported in detail elsewhere [12]. The diver gas space contained ambient air, and the incubation medium consisted of Krebs-Ringer phosphate buffer, which was placed as a small seal in the middle part of the diver neck. During the incubation period the islet rested on the lower meniscus of this seal. Just below was placed a side drop containing a test substance dissolved in phosphate medium. By application of a suitable positive pressure the seal with the islet could be made to move downward until it mixed with the side drop [12]. Each islet therefore served as its own control; the respiratory rate was determined first in a control medium for about $1 \mathrm{~h}$, and subsequently in a medium containing the test substance during the following hour. At the end of the experiments, the dry weights of incubated islets were determined in order to calculate the $\mathrm{QO}_{2}$-values ( $=$ oxygen uptake in $\mu \mathrm{l} / \mathrm{hour}$.mg dry tissue weight). The change of the islet respiratory rate upon addition of the test substance was also expressed in per cent of the control value. Statistical treatment of the data was performed as described by SNEDECOR [21].

Three series of experiments were carried out as follows: (A) To evaluate the effect of sulphonylureas on the endogenous respiratory rate, the oxygen uptake of islets incubated in a pure phosphate medium was compared with that recorded in the presence of one of the sulphonylurea compounds. (B) The effect of sulphonylureas on the respiration of the islet cells in the presence of glucose was studied by determinations of the oxygen uptake of islets, which had been incubated with glucose during the initial control period and sub- 
sequently with both glucose and sulphonylurea. (C) The influence of mannoheptulose on the oxygen uptake of islets in the presence of a sulphonylurea was determined by pre-incubation of islets with one of the latter compounds, followed by addition of mannoheptulose. In other experiments, islets were pre-incubated with mannoheptulose, and a sulphonylurea was subsequently added.

\section{Results}

The effects of different sulphonylureas on the endogenous respiratory rates of islet cells are summarized. in Table 1, which also shows a statistical evaluation of tion decreased to $92 \%$ of the control value. Analyses of data obtained with HB 419, added at a concentration of $0.1 \mu \mathrm{g} / \mathrm{ml}$ to islets pre-incubated in a phosphate medium with various glucose concentrations, indicated a decrease to $91 \%$ with $3 \mathrm{mg} / \mathrm{ml}$ of glucose; with $1 \mathrm{mg}$ of glucose/ml there was a slightly increased respiratory rate. At a low glucose concentration, $0.5 \mathrm{mg} / \mathrm{ml}$, HB 419 stimulated the oxygen uptake to the same extent as when no glucose was added.

Previous studies have shown that the diabetogenic sugar mannoheptulose strongly inhibits the glucosestimulated oxygen uptake of the islet B-cells [12]. In the present study some tests were performed to deter-

Table 1. Effects of different sulphonylureas on the endogenous respiratory rates of isolated pancreatic islets. The oxygen uptake $\left(-\mathrm{QO}_{2}\right)$ has been expressed as $\mu \mathrm{l} / \mathrm{h} . \mathrm{ng}$ dry weight. $P$ is probabitity of a chance difference from the initial respiratory rate. Means \pm S.E.M.

\begin{tabular}{|c|c|c|c|c|c|c|c|}
\hline \multirow{2}{*}{$\begin{array}{l}\text { No. of } \\
\text { animals }\end{array}$} & \multirow{2}{*}{$\begin{array}{l}\text { No. of } \\
\text { determi- } \\
\text { nations }\end{array}$} & \multirow{2}{*}{$\begin{array}{l}\text { I } \\
\text { Endogenous } \\
\text { respiration } \\
-\mathrm{QO}_{2}\end{array}$} & \multicolumn{5}{|c|}{$\begin{array}{l}\text { II } \\
\text { Respiration after addition of sulphonylurea }\end{array}$} \\
\hline & & & Sulphonylurea & $\begin{array}{l}\text { Conen. } \\
\mathrm{mg} / \mathrm{ml}\end{array}$ & $-\mathrm{QO}_{2}$ & $\begin{array}{l}\text { Oxygen uptake } \\
\text { as percentage } \\
\text { of } 1\end{array}$ & $P$ \\
\hline 2 & 8 & $4.5 \pm 0.3$ & D 860 & $10^{-1}$ & $5.2 \pm 0.2$ & $118.0 \pm 2.9$ & $<0.001$ \\
\hline 2 & 8 & $4.2 \pm 0.2$ & D $860-\mathrm{COOH}$ & $10^{-1}$ & $4.3 \pm 0.2$ & $101.6 \pm 0.5$ & $>0.05$ \\
\hline 2 & 5 & $4.5 \pm 0.2$ & HB 419 & $10^{-6}$ & $4.6 \pm 0.2$ & $102.7 \pm 0.8$ & $>0.05$ \\
\hline 3 & 8 & $3.9 \pm 0.6$ & НВ 419 & $10^{-5}$ & $4.6 \pm 0.7$ & $115.2 \pm 2.6$ & $<0.01$ \\
\hline 6 & 12 & $4.4 \pm 0.3$ & HB 419 & $10^{-4}$ & $5.4 \pm 0.4$ & $120.4 \pm 2.0$ & $<0.001$ \\
\hline 2 & 7 & $4.0 \pm 0.1$ & HB 419 & $10^{-3}$ & $4.7 \pm 0.2$ & $119.4 \pm 1.6$ & $<0.001$ \\
\hline 2 & 6 & $4.3 \pm 0.2$ & $\mathrm{HB} 419-\mathrm{OH}$ & $10^{-4}$ & $4.9 \pm 0.2$ & $114.7 \pm 1.7$ & $<0.001$ \\
\hline
\end{tabular}

the data. Tolbutamide in a concentration of $0.1 \mathrm{mg} / \mathrm{ml}$ increased the mean oxygen uptake to $118 \%$ of the control value, whereas the islet respiration was not affected by addition of its metabolite, D 860-COOH. When HB 419 was added, the endogenous respiration also increased considerably, and this effect appeared at a much lower concentration than with tolbutamide. In fact, maximal stimulation was found with only $0.1 \mu \mathrm{g}$ of $\mathrm{HB} 419 / \mathrm{ml}$; the respiration of the islet cells being $120 \%$ of the control rate. The corresponding value with HB 419 at a concentration of $1 \mu \mathrm{g} / \mathrm{ml}$ was $119 \%$. Even when the concentration was decreased to $0.01 \mu \mathrm{g} / \mathrm{ml}$, a marked respiratory stimulation was recorded, but no effect was observed with $0.001 \mu \mathrm{g} / \mathrm{ml}$. When the metabolite, HB 419-OH, was substituted for HB 419 at a concentration of $0.1 \mu \mathrm{g} / \mathrm{ml}$, the respiration of the incubated islet cells increased to $115 \%$ of that in the control medium. As shown in Fig. 1, addition of sulphonylurea to the incubation medium rapidly enhanced the endogenous oxygen uptake, which proceeded at the elevated rate for the remaining period of observation.

The action of sulphonylureas after pre-incubation of islets with glucose was studied in a series of experiments (Table 2). When tolbutamide $(0.1 \mathrm{mg} / \mathrm{ml})$ was added to islets respiring in a medium containing $3 \mathrm{mg} / \mathrm{ml}$ of glucose, the respiratory rate decreased slightly to $96 \%$ of that with glucose alone. In corresponding experiments with D 860-COOH the respira-

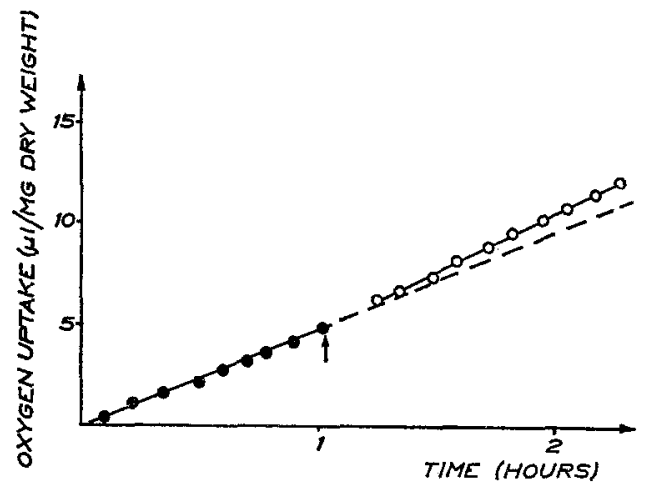

Fig. 1. Effect of HB 419 on the oxygen uptake of a single pancreatic islet incubated in Krebs-Ringer phosphate medium. The first part of the line $(-\ldots+-0)$ represents the endogenous respiratory rate, and the second part $(0-\ldots-0)$ the respiration after addition of HB $419(0.1 \mu \mathrm{g} / \mathrm{ml})$. The arrow indicates mixing of the buffer seal, including the islet, with the side drop. The broken line shows the extrapolated respiratory rate if HB 419 had not been added. The oxygen uptake increased by $21 \%$ after the addition of $\mathrm{HB} 419$

mine whether the respiratory response to sulphonylurea was modified by mannoheptulose. A first series of experiments included islets pre-incubated with HB 419 $(0.1 \mu \mathrm{g} / \mathrm{ml})$ and subsequently exposed to mannoheptulose at a concentration of $3 \mathrm{mg} / \mathrm{ml}$. As can be seen in 
Table 2, there was no evidence to indicate an inhibitory action of mannoheptulose; the respiratory rate of the islets remaining approximately constant throughout these experiments. Further tests showed, however, that pre-incubation of islets with mannoheptulose blocked the respiratory stimulation of $\mathrm{HB} 419$ on the islet cells. cose oxidation of these cells was not potentiated by sulphonylureas; on the contrary, the oxygen consumption at a high glucose concentration was slightly depressed. This agrees with a recent finding of $J_{\text {ARRETT }}$ [15], who observed no stimulation of ${ }^{14} \mathrm{CO}_{2}$-production from ${ }^{14} \mathrm{C}$-labelled glucose when tolbutamide was added

Table 2. Effects of different sulphonylureas on the respiratory rates of isolated pancreatic islets, which had been pre-incubated with various concentrations of glucose. The results of corresponding experiments with mannoheptulose are also shown. The oxygen uptake is expressed as in Table 1. Means $\perp$ S.E.M.

\begin{tabular}{|c|c|c|c|c|c|c|c|c|c|}
\hline \multirow[t]{2}{*}{$\begin{array}{l}\text { No. of } \\
\text { animals }\end{array}$} & \multirow{2}{*}{$\begin{array}{l}\text { No. of } \\
\text { determi- } \\
\text { nations }\end{array}$} & \multicolumn{3}{|c|}{$\begin{array}{l}\text { I } \\
\text { Respiration during initial } \\
\text { period of measurements }\end{array}$} & \multicolumn{5}{|c|}{$\begin{array}{l}\text { II } \\
\text { Respiration after mixing with side drop }\end{array}$} \\
\hline & & Addition & $\begin{array}{l}\text { Concn. } \\
\mathrm{mg} / \mathrm{ml}\end{array}$ & $-\mathrm{QO}_{2}$ & Addition & $\begin{array}{l}\text { Concn. } \\
\mathrm{mg} / \mathrm{ml}\end{array}$ & $-\mathrm{QO}_{2}$ & $\begin{array}{l}\text { Oxygen uptake } \\
\text { as percentage } \\
\text { of } \mathrm{I}\end{array}$ & $P$ \\
\hline 2 & 8 & Glucose & 3.0 & $9.3 \pm 0.5$ & $\mathrm{D} 860$ & $10^{-1}$ & $9.0 \pm 0.6$ & $95.8 \pm 1.3$ & $<0.05$ \\
\hline 2 & 6 & Glucose & 3.0 & $9.2 \pm 0.9$ & D 860 - COOH & $10^{-1}$ & $8.5 \pm 0.8$ & $92.1 \pm 1.1$ & $<0.01$ \\
\hline 1 & 5 & Glucose & 0.5 & $3.8 \mp 0.2$ & HB 419 & $10^{-4}$ & $4.5+0.3$ & $119.0 \pm 4.3$ & $<0.01$ \\
\hline 2 & 8 & Glucose & 1.0 & $4.4 \pm 0.3$ & $\mathrm{HB} 419$ & $10^{-4}$ & $4.6 \pm 0.3$ & $105.7 \pm 2.5$ & $<0.05$ \\
\hline $\overrightarrow{2}$ & 6 & Glucose & 3.0 & $8.6 \pm 0.6$ & HB 419 & $10^{-4}$ & $7.8 \pm 0.4$ & $90.6 \pm 1.3$ & $<0.01$ \\
\hline 3 & 10 & HB 419 & $10^{-4}$ & $5.6 \pm 0.3$ & $\begin{array}{l}\text { Manno- } \\
\text { heptulose }\end{array}$ & 3.0 & $5.6 \pm 0.3$ & $99.8 \pm 1.5$ & $>0.05$ \\
\hline 2 & 7 & $\begin{array}{l}\text { Manno- } \\
\text { heptulose }\end{array}$ & 3.0 & $4.6 \pm 0.3$ & HB 419 & $10^{-4}$ & $4.6 \pm 0.3$ & $101.4 \pm 1.1$ & $>0.05$ \\
\hline
\end{tabular}

\section{Discussion}

The present results clearly demonstrate both marked and highly reproducible effects of sulphonylureas on the respiratory metabolism of isolated islet cells. Moreover, the observations can be regarded as representative of the B-cells, since this cell type comprises over $90 \%$ of the total number of islet cells in obesehyperglycaemic mice. A marked stimulation of the oxygen uptake was recorded only in the absence of glucose or at a glucose concentration below $1 \mathrm{mg} / \mathrm{ml}$. These results suggest that addition of sulphonylureas brought about an increased rate of endogenous substrate oxidation, since sulphonylureas themselves probably do not serve as substrates in B-cell metabolism. The nature of endogenous substrates in the B-cells is so far unknown, but the supply appears sufficient to maintain a constant respiratory rate for hours [12]. In contrast to tolbutamide and HB 419, the pharmacologically inactive carboxylic acid of tolbutamide lacked a stimulating action on the respiration. This obviously did not depend on differences in cellular penetration, for the carboxylic acid derivative was effective in depressing the oxygen uptake of the islets in the presence of glucose. Whether the conformity between hypoglycaemic action and ability to stimulate endogenous respiration should be interpreted as signifying a close interaction between the endogenous rate of substrate oxidation and the insulin release, cannot be decided until more detailed data on the B-cell metabolism are available.

Glucose has previously been shown to stimulate strongly the oxygen consumption of the pancreatic $B$-cells $[11,12]$. The present findings indicate that glu- to isolated islets. These observations naturally do not exclude that sulphonylureas may still facilitate insulin secretion by modifications of the glucose break-down not reflected in the oxidative rate. In fact, CooRE and RANDLE [5] showed that addition of tolbutamide to pancreatic slices incubated in a bicarbonate medium was relatively more effective in promoting insulin release at a glucose concentration of $0.5 \mathrm{mg} / \mathrm{ml}$ than in the absence of the sugar. It was noteworthy, however, that tolbutamide affected the rate of hormone secretion to a relatively small extent when the glucose concentration was raised to $1.5 \mathrm{mg} / \mathrm{ml}$ or above.

In evaluating the present results, the question arises whether the particular action of sulphonylureas on the respiratory metabolism of the B-cells is confined to this cell type or shared also with other kinds of mammalian cells. Previous studies in vitro of kidney indicate that addition of sulphonylureas inhibits rather than stimulates the endogenous oxygen uptake of this tissue, whereas the results with liver are less uniform. With carbutamide, ClaRkE et al. [4] observed a marked inhibition of respiration in liver slices of rabbits; and with chlorpropamide CLARKE [3] reported a moderate inhibition in kidney slices of rats. On the other hand, DE SCHEPPER [7] recently demonstrated a stimulation of the endogenous oxygen uptake of rat liver slices with both tolbutamide and chlorpropamide, whereas the respiratory rate was inhibited in kidney slices. With tolbutamide in a concentration far above the therapeutic range, FREINKEL and INGBaR [9] found up to $50 \%$ inhibition of the respiratory rate in kidney slices of rabbits. In the rat diaphragm, the oxygen consumption increased upon addition of tolbutamide 
either in the absence of exogenous substrates [7] or in the presence of glucose $[18,19]$. It appears from these data that there are marked variations in the respiratory response of various tissues to sulphonylureas. These drugs seem, however, to increase the endogenous respiratory rate not only in the B-cells but also in the diaphragm, and possibly in the liver.

The observation that tolbutamide and HB 419 displayed very similar effects on the B-cell respiration in vitro, despite their concentrations in the medium being different by a stoichiometric factor of about 1000 , agrees well with previous findings on the blood sugar lowering effects in vivo of these drugs. When given orally to rabbits in a single dose of $25 \mathrm{mg} / \mathrm{kg}$ body weight, tolbutamide consistently decreased the blood sugar level by at least $10 \%$, whereas a corresponding effect with HB 419 was noted after administration of only $10 \mu \mathrm{g} / \mathrm{kg}$ body weight [1]. In man, the blood sugar level was similarly lowered by HB 419 with an oral dosage of only $15 \mu \mathrm{g} / \mathrm{kg}$ body weight. These observations, as well as those in the present study, support the view that $H B 419$ affects metabolic receptors in the B-cell at remarkably low concentrations. This holds true even when the B-cells were able in some, as yet unknown, way to concentrate sulphonylurea, since the present results in vitro indicate that the oxygen consumption was already significantly stimulated at a concentration in the incubation medium of $0.01 \mu \mathrm{g}$ of HB $419 \mathrm{ml}$. In these experiments the total amount of the drug in the medium was not more than $10^{-5} \mu \mathrm{g}$ in each individual diver experiment. Further studies to elucidate the metabolic action on the B-cells of this interesting substance are in progress.

\section{References}

1. Aumueller, W., A. Baemder, R. Heerdt, K. Muth, W. Pfafe, F.H. SchMid, H. WEBER u. R. WEYER: Ein neues, hochwirksames Antidiabeticum. Arzneimittel-Forsch. (Drug Res.) 16, 1640-1641 (1966).

2. Baender, A., W. Pfaff, F.H. Schmidt u. H. Stork: Zur Pharmakologie von Glibenclamid (HB 419), eines neuen oralen, hochwirksamen Antidiabeticums. To be published.

3. CLARKE, D.W.: Effects of administration of chlorpropamide upon the carbohydrate metabolism of isolated tissues. Ann. N.Y. Acad. Sci. 74, 478-481 (1959)

4. - M. Davidson, E. Schönbaum, and H. SEnMan: Some in vitro studies with BZ-55. Canad. med. Ass. J. 74, 966-968 (1956).

5. Coore, H.G., and P.J. RANDLE: Regulation of insusulin secretion studied with pieces of rabbit pancreas incubated in vitro. Biochem. J. 93, 66-78 (1964).

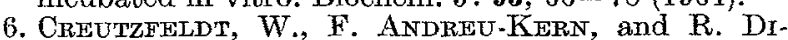
SCHER: Correlation of plasma levels of oral antidiabetic agents with blood sugar responses. Ann. N.Y. Acad. Sci. 82, $537-546$ (1959).
7. De SaHepper, P.J.: Metabolic effects of hypoglycemic sulfonylureas. I. In vitro effect of sulfonylureas on leucine incorporation and metabolism and on respiration of rat tissues. Biochem. Pharmacol. 16, 23372353 (1967).

8. Duncan, L.J.P., and B.F. Clarke: Pharmacology and mode of action of the hypoglycemic sulfonylureas and diguanides. Ann. Rev. Pharmacol. 5, 151-162 (1965).

9. Freinkel, N., and S.H. IngBar: The effects of the arylsulfonylureas on the respiratory activity and glucose metabolism of isolated rabbit kidney cortex. Endocrinology 64, 1002-1009 (1959).

10. Helterström, C.: A method for the microdissection of intact pancreatic islets of mammals. Acta endoer. (Kbh.) 45, 122-132 (1964).

11. - Oxygen consumption of isolated pancreatic islets of mice studied with the Cartesian-diver microgasometer. Biochem. J. 98, 7c-9c (1966).

12. - Effects of carbohydrates on the oxygen consumption of isolated pancreatic islets of mice. Endocrinology 81, 105-112 (1967).

13. HEPTNER, W.: Personal communication.

14. Holter, H., and $K$. Linderström-LANG: On the Cartesian diver. C.R. Lab. Carlsberg 24, 333-478 (1943).

15. JaRretr, J.: Personal communication.

16. Loubatuères, A.: Physiologie et Pharmacodynamie de certains dérivés sulfamidés hypoglycémiants. Contribution à l'étude des substances synthétiques à tropisme endocrinien. Causse, Graille et Castelnau éditeurs, p. 84. Montpellier: 1946.

17. - Etude physiologique et pharmacodynamique de certains dérivés sulfamidés hypoglycémiants. Arch. int. Physiol. (Paris) 54, 174-177 (1946).

18. Mohnike, G., K.W. KNItsch, H. Boser, G. WerNER u. S. WERNER: Untersuchungen über die Wirkung von $\mathrm{N}$-(4-Methyl-benzolsulfonyl)- $\mathrm{N}^{\prime}$-butylHarnstoff (D 860) an Geweben und Fermenten in vitro. Dtsch. med. Wschr. 82, 1580-1581 (1957).

19. Pletscher, A., u. K.F. GeY: Über die Wirkung blutzuckersenkender Sulfonylharnstoffe auf das isolierte Rattenzwerchfell. Experientia (Basel) 13, 447-449 (1957).

20. Stork, H., Schmidt, F.H., A. Bänder u. W. Pfaff: Der Einfluß von HB 419 - einem neuen oralen Antidiabeticum - auf den Fettstoffwechsel. To be published.

21. SNeDecor, G.W.: Statistical Methods, 5th Ed. p. 49. Iowa: Iowa State University Press 1956.

22. UMBREIT, W.W., R.H. BuRRTS, and J.F. STAUTFER: Manometric Techniques, p. 131. Minneapolis: Burgess Publishing Company 1964.

23. Wrlltams, R.H.: Oral drugs in diabetes. In: Williams, R.H. (ed.), Diabetes with a chapter on hypoglycemia, p. 481. New York: Paul H. Hoeber 1960.

24. Wittenhaghe, G., G. MohntKe u. W. Langenbeck: Beiträge zum Abbau und Ausscheidung von N-(4Methyl-benzolsulfonyl-N'-butyl-Harnstoff. HoppeSeylers Z. physiol. Chem. 316, $157-163$ (1959).

\author{
Dr. med. Harald StorK \\ Boehringer Mannheim GmbH \\ Physiol.-chem. Labor \\ 68 Mannheim-Waldhof \\ Sandhoferstraße $116-132$
}

